\title{
Preliminary Phytochemical Screenings and Pharmacological Activities of Three Medicinal Plants of Bangladesh
}

\author{
Mohammed Ibrahim ${ }^{1}$, Md. Ruhul Kuddus ${ }^{1}$, Md. Aslam Hossain ${ }^{1}$, \\ Muhammad Abdullah Al-Mansur ${ }^{2}$ and Mohammad A. Rashid ${ }^{1}$ \\ ${ }^{2}$ Department of Pharmaceutical Chemistry, Faculty of Pharmacy, University of Dhaka \\ Dhaka-1000, Bangladesh \\ ${ }^{2}$ Institute of National Analytical Research and Services (INARS), BCSIR, Dhaka-1205, Bangladesh
}

(Received: September 20, 2017; Accepted: October 28, 2017; Published (web): December 23, 2017)

\begin{abstract}
The present study was designed to evaluate the preliminary phytochemical screening and antimicrobial, antidiarrheal, anti-inflammatory, analgesic, antipyretic, anxiolytic, thrombolytic and membrane stabilizing properties of the methanolic extract of three medicinal plants Perilla ocymoides L., Murraya koenigii (Linn.) Spreng., Baliospermum montanum (Wild.) Muell growing in Bangladesh. In antimicrobial test, maximum zone of inhibition was found against Salmonella typhi $(18.0 \mathrm{~mm})$ and Escherichia coli $(17.0 \mathrm{~mm})$ by B. montanum extract. In the castor oil-induced antidiarrheal assay, the methanol extract of $M$. koenigii showed maximum 50\% inhibition of defecation. During in-vitro anti-inflammatory test, the methanol extract of B. montanum at $500 \mu \mathrm{g} / \mathrm{ml}$, b.w. revealed $39.62 \%$ inhibition of protein denaturation. Due to analgesia, the M. koenigii extract showed 53.29\% inhibition of acetic acidinduced writhing reflex in experimental mice. Antipyretic effect of P. ocymoides, M. Koenigii and B. montanum extractives was assessed by Brewer's yeast-induced pyrexia in mice. The B. montanum extract possesses significant anxiolytic effect that was evidenced by both hole cross test and open field test in mice. In thrombolytic assay, the highest activity $(57.81 \%)$ was observed by B. montanum extract. Results of the preliminary phytochemical screenings demonstrated the presence of alkaloids, glycosides, flavonoids, reducing sugars, gums etc.
\end{abstract}

Key words: Perilla ocymoides, Murraya koenigii, Baliospermum montanum, antimicrobial, antidiarrheal, antiinflammatory, analgesic, antipyretic, anxiolytic, thrombolytic, membrane stabilizing.

\section{INTRODUCTION}

Bangladesh is a prominent source of numerous medicinal plants among the South Asian countries. About 250 species of medicinal plants are used for the preparation of traditional medicines which is the half of total species of plants grown in Bangladesh. ${ }^{1}$ But the uses of most of these plants have no scientific basis. The majority of these plants have not yet undergone extensive chemical, pharmacological, and toxicological studies to identify their bioactive compound(s). Therefore, evaluation of medicinal plants with important biological activity is an essential task to discover new lead compounds from natural sources. ${ }^{2,3}$

Correspondence to: Mohammad A. Rashid

Tel.: +88-02-9661900-73, Extn.8137

Fax: +88-02-9667222; E-mail: rashidma @du.ac.bd.

Dhaka Univ. J. Pharm. Sci. 16(2): 195-203, 2017 (December)
Perilla ocymoides L. (Bengali name: Ban tulsi; Family: Lamiaceae) is an annual herb of the mint family which is an edible plant and native to East Asia. The entire plant is rich in vitamins and minerals. ${ }^{4}$ It has antiasthmatic, antidote, antimicrobial, antipyretic, antiseptic, anti-allergic properties. ${ }^{5,6}$ The seeds of Perilla species contain different polyphenols or flavones. The essential oil of the plant is used as flavouring agent in food industry.

Murraya koenigii (Linn.) Spreng. (Family: Rutaceae), commonly termed as curry leaves, is basically known for its smell and medicinal property. This plant has been reported to show antidiabetic and immunomodulatory effects. ${ }^{7,8}$ The aromatic leaves used in cooking curry are reported to possess antioxidant, antidiabetic, anti-inflammatory, hepatoprotective and hypolipidemic activities. ${ }^{9-12}$ 
The carbazole alkaloids isolated from leaves are suggested to have stimulating effects on the central nervous system. ${ }^{13}$

Baliospermum montanum (Wild.) Muell. is a Bangladeshi medicinal plant which belongs to Euphorbiaceae family. The roots, leaves and seeds of this plant are used medicinally for different activities. Root is used in abdominal pain, constipation, piles, calculus, helminthiasis and scabies. The leaves are used in treating asthma and seeds are used in snakebite. Recently, the ethanolic extract of leaves of this plant has shown antimicrobial activity against test microorganisms. The plant contains phorbol esters, 12-deoxyphorbol and 12-deoxy-16hydroxyphorbol which are reported to exhibit antilukaemic and cytotoxic activities. ${ }^{14,15}$

As part of our continuing studies on medicinal plants of Bangladesh, ${ }^{16,17}$ we conducted phytochemical- and pharmacological-screenings of methanol extract of three Bangladeshi medicinal plants i.e., Perilla ocymoides, Murraya koenigii, Baliospermum montanum as well as to find out the logical evidence for their folk uses.

\section{MATERIALS AND METHODS}

Plant materials. The seeds of Perilla ocymoides, leaves of both Murraya koenigii and Baliospermum montanum were collected from Naramuk, Rajasthali of Rangamati district, Bangladesh in June 2010 and were identified at the Forest Research Institute, Chittagong, Bangladesh, where voucher specimens have been maintained for future reference.

Drying and grinding. The collected plant materials were washed with running tap water and then were dried at a temperature not exceeding $40^{\circ} \mathrm{C}$ in an oven. The dry materials were ground to a coarse powder with the help of a grinding machine and kept in an airtight container until extraction was commenced.

Hot extraction. The powdered materials $(150 \mathrm{~g}$ each) were extracted with $750 \mathrm{ml}$ of methanol (99.98\%) in a Soxhlet apparatus (Quickfit, England). The extracts were separately concentrated with a rotary evaporator (Heidolph, Germany) under reduced temperature and pressure to provide gummy residues.

Chemicals. All chemicals and solvents used in this study were of analytical grade and purchased from Merck, Germany. Standard drugs such as loperamide, acetyl salicylic acid (ASA), diclofenac$\mathrm{Na}$, paracetamol, and diazepam were obtained from Square Pharmaceuticals Ltd. as gift samples.

Experimental animals. Swiss Albino mice (25$30 \mathrm{~g}$ ) of either sex, 6-7 weeks of age, were collected from the Animal Resources Branch of the International Centre for Diarrheal Disease and Research, Bangladesh (icddr,b). The mice were maintained under standard laboratory conditions ${ }^{18}$ of temperature $\left(27.0 \pm 1.0^{\circ} \mathrm{C}\right)$, relative humidity $(55$ $65 \%)$ and $12 \mathrm{hr}$ light/12 hr dark cycle. The animals are fed with icddr,b formulated diet and water ad libitum.

Preliminary phytochemical investigations. For preliminary phytochemical investigation, the crude methanol extracts of $P$. ocymoides, $M$. koenigii and $B$. montanum were subjected to various tests (Table 1) to determine the chemical nature of the extracts. ${ }^{19-21}$

Test for antimicrobial activity. The preliminary antimicrobial activity of $P$. ocymoidies, $M$. koenigii and $B$. montanum extractives were determined by the disc diffusion method ${ }^{22}$ against a number of Gram positive and Gram negative bacteria and fungi (Table 2). The bacterial and fungal strains used in this experiment were collected from the Microbiology Lab., Chittagong University, Chittagong, Bangladesh. Here, standard ciprofloxacin $(30 \mu \mathrm{g})$ and fluconazole $(30 \mu \mathrm{g})$ discs were used as references.

Test for anti-diarrheal activity. The $P$. ocymoides, M. koenigii and B. montanum extractives were subjected to assay for anti-diarrheal activity which was carried out by castor oil-induced diarrhea in mice. ${ }^{23}$ For this purpose, the animals were divided into negative control, positive control and three test groups containing five mice in each. The negative control group mice received 1\% Tween-80 $(10 \mathrm{ml} / \mathrm{kg}$, p.o). The positive control group received loperamide (3 $\mathrm{mg} / \mathrm{kg}$ b.w., p.o.), while the test groups were 
administered with each of the methanol extract (500 $\mathrm{mg} / \mathrm{kg}$, b.w.) orally. Acute diarrhea was induced by oral administration of $0.4 \mathrm{ml}$ of castor oil to each mouse. Then the latency period and diarrheic secretion were counted for 4 hours using standard protocol. ${ }^{23}$

Test for anti-inflammatory activity. To determine the anti-inflammatory activity of the $P$. ocymoides, M. koenigii and B. montanum extractives, 15 clean centrifuge tubes (three for standard acetyl salicylic acid, three for negative control methanol and three for each crude extract) were used. Then, $1.0 \mathrm{ml}$ of 5\% egg albumin solution was added to all test tubes. Later on, $1.0 \mathrm{ml}$ of acetyl salicylic acid (0.1 $\mathrm{mg}), 1.0 \mathrm{ml}$ of Tween- 80 and $1.0 \mathrm{ml}$ of crude extract $(500 \mu \mathrm{g} / \mathrm{ml}$ of Tween-80) were added to the positiveand negative-controls and test groups, respectively. All the reaction mixtures were adjusted to $\mathrm{pH} 5.6 \pm 0.2$ by $1 \mathrm{~N} \mathrm{HCl}$, heated, cooled and finally, after filtration, the absorbance was measured spectrophotometrically at $660 \mathrm{~nm}^{24}$

Test for analgesic activity. The analgesic activity of the $P$. ocymoides, $M$. koenigii and $B$. montanum extractives was evaluated using acetic acid-induced writhing method in mice. ${ }^{25}$ Experimental animals were divided into negative control, positive control and three test groups containing five mice in each. The mice of each group received a particular treatment i.e. negative control, standard drug and one dose of each extract. Test samples $(500 \mathrm{mg} / \mathrm{kg}$, b.w. of the plant extract), $1 \%$ Tween- 80 and diclofenac-Na were given orally by means of feeding needle. An interval of thirty minutes was given to ensure proper absorption of the administered substances. Then, the writhing inducing chemical acetic acid solution $(0.7 \%, 15 \mathrm{ml} / \mathrm{kg}$ b.w.) was administered intraperitoneally to all mice. After an interval of 5 mins, which was given for absorption of acetic acid, number of squirms (writhing) was counted for 5 mins.

Test for antipyretic activity. The antipyretic activity of the $P$. ocymoides, $M$. koenigii and $B$. montanum extractives was evaluated on Swiss Albino mice $(25-30 \mathrm{~g})$ of either sex. The animals were divided into five groups, each group containing five mice. The normal body temperature of each mouse was recorded using digital thermometer and then pyrexia was induced in all mice by injecting $20 \%$ aqueous suspension of Brewer's yeast $(10 \mathrm{ml} / \mathrm{kg}$ b.w., s.c.). ${ }^{26}$ All groups were fasted overnight but free access to drinking water was provided. After $24 \mathrm{~h}$, rectal temperature of each mouse was recorded again. The induction of pyrexia was confirmed by rise in temperature of more than $32.9^{\circ} \mathrm{F}$, while animals showing less than $32.9^{\circ} \mathrm{F}$ rise of temperature were excluded from the experiment. Group-I received saline $(10 \mathrm{ml} / \mathrm{kg}$, b.w.) as a negative control, group-II received paracetamol $(150 \mathrm{mg} / \mathrm{kg}$, b.w.) as standard drug while the test groups received $500 \mathrm{mg} / \mathrm{kg}$ b.w. of the plant extract, respectively. Rectal temperature was recorded periodically after 1,2 and $3 \mathrm{hrs}$ of drugs administration.

\section{Test for anxiolytic activity}

Treatment schedule. The anxiolytic activity of the plant extractives was examined by using the hole board test and open field test. The animals were divided in to five groups, with each group consisting of three mice. First group received normal saline, second group received diazepam $(1 \mathrm{mg} / \mathrm{kg}$ b.w.) and the remaining groups received plant extract (500 $\mathrm{mg} / \mathrm{kg}$ b.w.).

Hole cross test. The hole board is a white painted wooden board $(30 \mathrm{~cm} \times 20 \mathrm{~cm} \times 14 \mathrm{~cm})$ with 16 holes (each of diameter $3 \mathrm{~cm}$ ) evenly distributed on the base of box. The test groups received crude extract at the dose of $500 \mathrm{mg} / \mathrm{kg}$ b.w. orally whereas the negative- and positive- control group mice received saline and diazepam (2 $\mathrm{mg} / \mathrm{kg}$, i.p.), respectively. The number of passages of a mouse through the hole from one chamber to the other was counted for a period of $30 \mathrm{~min}$ after $30 \mathrm{~min}$ of oral administration of the test drug. ${ }^{27}$

Open field test. The open field test is employed to observe general motor activity, exploratory behavior and measure anxiety. The open field area was made of plain wood and consisted of a square area $(45 \mathrm{~cm} \times 45 \mathrm{~cm} \times 20 \mathrm{~cm})$. The floor had a 
square sheet of wood $(45 \mathrm{~cm} \times 45 \mathrm{~cm})$ with the surface divided into sixteen small squares. Experimental animals were divided into five groups of 3 mice and treated similarly as described in the hole cross test. About $30 \mathrm{~min}$ after treatment, mice of both the control and treated groups were placed individually in the center of the open field and behavioral activities were video recorded for $30 \mathrm{~min}$. Subsequently, hand operated counters and stopwatches were used to score the following behavioral parameters for a period of $30 \mathrm{~min}$ : (1) the number of entries and time spent in the centre, (2) periphery and corners of the field, (3) the number of crossings (number of square floor units entered) as a measure of distance travelled, (4) rearing (number of times the animal stood on hind legs) and (5) assisted rearing (forepaws touching the walls of the apparatus). ${ }^{27}$

Test for thrombolytic activity. The thrombolytic activity of the $P$. ocymoides, $M$. koenigii and $B$. montanum extractives was evaluated following the method developed by Prasad et al. ${ }^{28}$ using streptokinase as standard.

Test for membrane stabilizing activity. The membrane stabilizing activity of all extracts was assessed by hypotonic solution-induced erythrocyte hemolysis designed by Shinde et al. ${ }^{29}$ using acetyl salicylic acid as standard.

Statistical analysis. Results are expressed as the mean \pm SEM. Statistical analysis for animal experiment was carried out using one-way ANOVA followed by Dunnett's multiple comparisons. The results obtained were compared with the vehicle control group, where $\quad \mathrm{p}<0.05$ was considered as statistically significant.

\section{RESULTS AND DISCUSSION}

Phytochemical tests. The phytochemical screenings of $P$. ocymoides, $M$. koenigii, and $B$. montanum extractives revealed the occurrence of various bioactive secondary metabolites such as alkaloids, glycosides, flavonoids, reducing sugars, gums etc. (Table 1). All these extracts contained alkaloids, flavonoids and reducing sugars while steroids and tannins were present only in $M$. koenigii extract and $P$. ocymoides extract, respectively. The presence of biologically important phytochemicals in the $P$. ocymoidies, $M$. koenigii and $B$. montanum extractives, is believed to contribute to their medicinal values, and therefore, point to potential sources for useful drugs.

Antimicrobial activity. $P$. ocymoides, $M$. koenigii, and B. montanum extracts were screened for antibacterial and antifungal activities by employing the disc diffusion method. ${ }^{22}$ The activity was recorded as diameter of zone of inhibition using the crude extract at the concentration of $500 \mu \mathrm{g} /$ disc. During screening for antibacterial activity, all the plant extracts exhibited mild to strong antibacterial activity (zone of inhibition $=9.0-18.0 \mathrm{~mm}$ ) against both Gram positive and Gram negative bacteria (Table 2). Among all test organisms, $S$. Typhi and $E$. coli were found to be most sensitive to $B$. montanum extracts. On the other hand, the extracts of both $P$. ocymoides and $M$. koenigii showed moderate antifungal (zone of inhibition $=9.0-16.0 \mathrm{~mm}$ activity while $B$. montanum did not show any activity against the fungal species (Table 2) used in the screening.

Antidiarrheal activity. In castor oil-induced diarrhea, crude extract of $P$. ocymoides, $M$. koenigii and $B$. montanum at $500 \mathrm{mg} / \mathrm{kg}$ b.w. revealed different degrees of anti-diarrheal activity as evident by the reduction of defecation (Table 3 ). In general, the imbalance between the absorptive and secretory mechanisms in the intestinal tract leads to induce diarrhea. Ricilonic acid, an active component of castor oil, stimulates the peristaltic activity in the small intestine, leading to changes in the electrolyte permeability of the intestinal mucosa. In this study, the plant extracts exhibited prominent anti-diarrheal activity, which may be attributed to the phytochemical constituents such as flavonoids, tannins, saponins etc. ${ }^{30}$

In vitro anti-inflammatory activity. In the present study for in vitro anti-inflammatory properties, the crude methanol extract of $B$. montanum and M. koenigii at $500 \mu \mathrm{g} / \mathrm{ml}$ showed $39.62 \%$ and $32.08 \%$ inhibition of protein 
denaturation, respectively whereas standard ASA ability of $P$. ocymoides extract was found to be mild exhibited $62.26 \%$ (Table 4). On the other hand, the in inhibiting heat-induced protein denaturation.

Table 1. Chemical analysis for phytoconstituents in crude methanol extract of P. ocymoides, M. koenigii and B. montanum.

\begin{tabular}{|c|c|c|c|c|c|c|c|c|}
\hline \multirow{2}{*}{ Plant extract } & \multicolumn{8}{|c|}{ Chemical groups } \\
\hline & Alkaloids & Glycosides & Steroids & Tannins & Flavonoids & Saponins & Gums & Amides \\
\hline P. ocymoides & + & - & - & + & + & - & + & - \\
\hline M. koenigii & + & + & + & - & + & - & - & - \\
\hline B. montanum & + & + & - & - & + & - & + & - \\
\hline
\end{tabular}

Table 2. Antimicrobial activity of methanol extract of P. ocymoides, M. koenigii and B. montanum.

\begin{tabular}{|c|c|c|c|c|}
\hline \multirow[b]{2}{*}{ Microorganisms } & \multicolumn{4}{|c|}{ Diameter of zone of inhibition (mm) } \\
\hline & $\begin{array}{c}\text { POME } \\
(500 \mu \mathrm{g} / \text { disc })\end{array}$ & $\begin{array}{c}\text { MKME } \\
(500 \mu \mathrm{g} / \text { disc })\end{array}$ & $\begin{array}{c}\text { BMME } \\
(500 \mu \mathrm{g} / \text { disc })\end{array}$ & $\begin{array}{l}\text { Ciprofloxacin } \\
(30 \mu \mathrm{g} / \mathrm{disc})\end{array}$ \\
\hline \multicolumn{5}{|l|}{ Gram positive bacteria } \\
\hline Bacillus cereus & $15.0 \pm 0.60$ & $13.0 \pm 1.03$ & $14.0+0.59$ & $22.0 \pm 0.09$ \\
\hline B. megaterium & $11.0 \pm 0.36$ & $15.0 \pm 0.62$ & $16.0+0.15$ & $25.0 \pm 1.53$ \\
\hline B. subtilis & $12.0 \pm 1.45$ & - & $11.0+0.28$ & $21.0 \pm 0.42$ \\
\hline Staphylococcus aureus & $12.0 \pm 1.61$ & $12.0 \pm 1.57$ & - & $28.0 \pm 0.65$ \\
\hline \multicolumn{5}{|l|}{ Gram negative bacteria } \\
\hline Escherichia coli & - & $14.0 \pm 0.47$ & $17.0+0.75$ & $23.0 \pm 1.05$ \\
\hline Pseudomonas aeruginosa & $14.0 \pm .57$ & $12.0 \pm 0.58$ & $9.0+0.09$ & $26.0 \pm 0.56$ \\
\hline Salmonella paratyphi & $14.0 \pm 0.80$ & $9.0 \pm 1.25$ & $14.0+1.25$ & $23.0 \pm 1.25$ \\
\hline S. typhi & $15.0 \pm 1.58$ & $17.0 \pm 1.03$ & $18.0+0.15$ & $28.0 \pm 0.76$ \\
\hline Shigella dysenteriae & $12.0 \pm 0.57$ & $12.0 \pm 0.57$ & - & $25.0 \pm 0.83$ \\
\hline Sh. sonnei & $13.0 \pm 0.47$ & $16.0 \pm 1.63$ & $13.0+0.33$ & $22.0 \pm 0.59$ \\
\hline Vibrio cholerae & $15.0 \pm 1.70$ & $15.0 \pm 1.08$ & $10.0+0.57$ & $23.0 \pm 1.34$ \\
\hline Fungi & & & & $\begin{array}{r}\text { Fluconazole } \\
(30 \mu \mathrm{g} / \mathrm{disc})\end{array}$ \\
\hline Aspergillus niger & $12.0 \pm 0.57$ & $14.0 \pm 0.64$ & - & $26.0 \pm 0.12$ \\
\hline Blastomyces dermatitidis & $15.0 \pm 1.88$ & $11.0 \pm 1.45$ & & $22.0 \pm 0.13$ \\
\hline Candida albicans & $10.0 \pm 0.49$ & $11.0 \pm 0.76$ & $\cdot$ & $22.0 \pm 0.57$ \\
\hline Cryptococcus neoformans & $12.0 \pm 0.76$ & $13.0 \pm 0.35$ & $\cdot$ & $25.0 \pm 1.22$ \\
\hline Microsporum spp. & $11.0 \pm 0.55$ & $13.0 \pm 0.34$ & $\cdot$ & $24.0 \pm 0.55$ \\
\hline Pityrosporum ovale & $12.0 \pm 2.08$ & $09.0 \pm 1.15$ & $\cdot$ & $26.0 \pm 1.12$ \\
\hline Trichophyton spp. & $10.0 \pm 1.09$ & $16.0 \pm 0.67$ & $\cdot$ & $23.0 \pm 0.99$ \\
\hline
\end{tabular}

Values are expressed as mean $\pm \mathrm{SEM}$, Zones of inhibition $<8 \mathrm{~mm}$ were discarded. POME $=$ Methanolic extract of Perilla ocymoides, MKME $=$ Methanolic extract of Murraya koenigii, BMME = Methanolic extract of Baliospermum montanum 
Table 3. Antidiarrheal activity of $P$. ocymoides, M. koenigii and B. montanum extractives in mice.

\begin{tabular}{lcc}
\hline Test groups & \% Inhibition of defecation & TNF $(240 \mathrm{~min})^{*}$ \\
\hline Negative control & 0 & $98.00 \pm 1.35$ \\
Loperamide (3mg/kg, b.w.) & 65.31 & $34.00 \pm 1.34$ \\
POME (500 mg/kg, b.w.) & 37.76 & $61.00 \pm 1.14$ \\
MKME (500 mg/kg, b.w.) & 50.00 & $49.00 \pm 1.43$ \\
BMME (500 mg/kg, b.w.) & 39.80 & $59.00 \pm 1.64$ \\
\hline
\end{tabular}

$* \mathrm{TNF}=$ Total number of faeces $(\mathrm{MD} \times 5 \pm \mathrm{SEM})$

Table 4. In vitro anti-inflammatory activity of the P. ocymoides, M. koenigii and B. montanum extractives.

\begin{tabular}{lc}
\hline \multicolumn{1}{c}{ Test groups } & Total inhibition of protein denaturation \\
\hline Negative control & $0 \pm 0.001$ \\
Standard ASA $(0.1 \mathrm{mg} / \mathrm{ml})$ & $62.26 \pm 0.001$ \\
POME $(500 \mu \mathrm{g} / \mathrm{ml})$ & $18.87 \pm 0.001$ \\
MKME $(500 \mu \mathrm{g} / \mathrm{ml})$ & $32.08 \pm 0.008$ \\
BMME $(500 \mu \mathrm{g} / \mathrm{ml})$ & $39.62 \pm 0.001$ \\
\hline
\end{tabular}

Table 5. Analgesic activity of $P$. ocymoides, $M$. koenigii and B. montanum extracts on acetic acid-induced writhing in mice.

\begin{tabular}{|c|c|c|c|c|}
\hline Clinical groups & Total writhing & $\%$ Writhing & $\%$ Protection & $\begin{array}{c}\mathrm{t}-\text { test } \\
\text { (p-values) }\end{array}$ \\
\hline Control (1\% Tween-80) & $170.0 \pm 2.35$ & 100 & 0 & - \\
\hline $\begin{array}{l}\text { Diclofenac-Na ( } 25 \mathrm{mg} / \mathrm{kg} \text {, } \\
\text { b.w.) }\end{array}$ & $51.0 \pm 0.82$ & 30 & 70 & $\begin{array}{c}9.58 \\
(\mathrm{p}<0.0003)\end{array}$ \\
\hline POME (500 mg/kg, b.w.) & $110.0 \pm 0.50$ & 64.71 & 35.29 & $\begin{array}{c}6.84 \\
(p<0.004)\end{array}$ \\
\hline MKME(500 mg/kg, b.w.) & $76.0 \pm 1.53$ & 44.71 & 53.29 & $\begin{array}{c}6.84 \\
(p<0.001)\end{array}$ \\
\hline BMME(500 mg/kg, b.w.) & $155.0 \pm 2.37$ & 91.18 & 8.82 & $\begin{array}{c}0.899 \\
(\mathrm{p}<0.05)\end{array}$ \\
\hline
\end{tabular}

Table 6. Antipyretic effect of $P$. ocymoides, $M$. koenigii and B. montanum extractives on yeast-induced pyrexia in mice.

\begin{tabular}{|c|c|c|c|c|}
\hline \multirow{2}{*}{ Drug } & \multicolumn{4}{|c|}{ Rectal temperature in ${ }^{\circ} \mathrm{F}$ at time (hr) after administration of drug } \\
\hline & $0 \mathrm{hr}$ & $1 \mathrm{hr}$ & $2 \mathrm{hrs}$ & $3 \mathrm{hrs}$ \\
\hline $\begin{array}{l}\text { Control } \\
{[\mathrm{DW}, 10 \mathrm{ml} / \mathrm{kg}]}\end{array}$ & $101.23 \pm 0.71$ & $101.41 \pm 0.36$ & $101.74 \pm 0.58$ & $101.32 \pm 0.77$ \\
\hline $\begin{array}{l}\text { Paracetamol } \\
(150 \mathrm{mg} / \mathrm{kg}, \text { b.w. })\end{array}$ & $102.38 \pm 0.57$ & $99.47 \pm 0.82$ & $97.56 \pm 0.73$ & $96.49 \pm 0.85$ \\
\hline $\begin{array}{l}\text { POME } \\
(500 \mathrm{mg} / \mathrm{kg}, \text { b.w.) }\end{array}$ & $101.52 \pm 0.19$ & $100.43 \pm 0.88$ & $99.14 \pm 0.32$ & $97.85 \pm 0.59$ \\
\hline $\begin{array}{l}\text { MKME } \\
(500 \mathrm{mg} / \mathrm{kg} \text {, b.w.) }\end{array}$ & $102.56 \pm 0.37$ & $101.63 \pm 0.41$ & $101.05 \pm 0.18$ & $98.74 \pm 0.22$ \\
\hline $\begin{array}{l}\text { BMME } \\
\text { (500 mg/kg, b.w.) }\end{array}$ & $101.37 \pm 0.43$ & $101.13 \pm 0.59$ & $101.22 \pm 0.17$ & $99.98 \pm 0.32$ \\
\hline
\end{tabular}


Analgesic activity. The analgesic effect of $P$. ocymoides, $M$. koenigii and B. montanum extractives on the acetic acid-induced abdominal constrictions in mice has been presented in table 5 . The results show that the plant extract $(500 \mathrm{mg} / \mathrm{kg} \mathrm{b.w.})$, and the reference drug diclofenac-Na $(25 \mathrm{mg} / \mathrm{kg} \quad$ b.w. $)$ significantly reduced abdominal writhing in mice.

Antipyretic activity. The methanolic crude extract of $P$. ocymoides, $M$. koenigii and $B$. montanum markedly diminished yeast-induced hyperthermia in mice. The inhibition remained significant up to 3 hour of administration as shown in table 6. About three hour of drug administration, the maximum antipyretic effect was observed by $P$. ocymoides extractive i.e., $97.85^{\circ} \mathrm{F}$ while the antipyretic effect of paracetamol $(150 \mathrm{mg} / \mathrm{kg})$ was $96.49^{\circ} \mathrm{F}$. The antipyretic effects of the extracts were compared with that of standard paracetamol (Table 6).

Table 7. Anxiolytic activity of $P$. ocymoides, $M$. koenigii and $B$. montanum extracts in mice.

\begin{tabular}{lcccc}
\hline \multirow{2}{*}{ Clinical groups } & \multicolumn{2}{c}{ Hole cross test } & \multicolumn{2}{c}{ Open field test } \\
\cline { 2 - 5 } & Number of hole crossed & $\begin{array}{c}\text { \% Inhibition of } \\
\text { hole cross }\end{array}$ & $\begin{array}{c}\text { Number of square } \\
\text { crossed }\end{array}$ & $\begin{array}{c}\text { \% Inhibition } \\
\text { of square crossed }\end{array}$ \\
\hline Normal saline & $33.99 \pm 0.41$ & 0 & $240.99 \pm 2.95$ & 0 \\
Diazepam $(1.0 \mathrm{mg} / \mathrm{kg})$ & $8.01 \pm 0.41$ & 76.52 & $36.0 \pm 2.12$ & 85.06 \\
POME(400mg/kg) & $32.01 \pm 1.08$ & 6.50 & $198.0 \pm 3.08$ & 17.84 \\
MKME(400mg/kg) & $27.00 \pm 0.71$ & 20.62 & $219.0 \pm 1.87$ & 9.12 \\
BMME(400mg/kg) & $21.99 \pm 1.08$ & 35.34 & $152.01 \pm 3.19$ & 36.92 \\
\hline
\end{tabular}

Anxiolytic activity. During the evaluation of anxiolytic activity by hole cross test, the plant extracts at $500 \mathrm{mg} / \mathrm{kg}$, b.w. showed significant increase in the number of line crossing as compared to control animals as shown (Table 7). In the open field test, administration of plant extract in mice demonstrated substantial increase in number of squares crossed as compared to the control (Table 7). Medicinal plants are a good source to find new remedies for anxiety disorders. Mechanism of anxiolytic action of plants might be due to the interaction with some of the natural endogenous mediators in the body. ${ }^{31}$ There could also be a linkage in the interaction of the plant extract with serotonergic pathway. $^{32}$ Thus the present study revealed that the plant extracts specially $B$. montanum extract possesses significant anxiolytic effect.

Thrombolytic activity. The purpose of this experiment was to identify the fibrinolytic drugs from natural sources. These drugs are used for the treatment of myocardial infarction to dissolve the thrombin in occluded coronary arteries and thereby helpto restore normal blood supply to ischemic myocardium. $^{33}$ As shown in table 8, streptokinase (SK), a positive control (30,000I.U.) showed 69.23\% lysis of clot after incubation with clot of human blood at $37^{\circ} \mathrm{C}$ for 90 minutes. In this study, the highest thrombolytic activity $(57.81 \%)$ was observed by $B$. montanum extract (Table 8).

Table 8. Thrombolytic effect (\%clot lysis) and membrane stabilizing effect of $P$. ocymoides, $M$. koenigii and $B$. montanum extract.

\begin{tabular}{lcc}
\hline Samples & \% Clot lysis & $\begin{array}{c}\text { \% Inhibition of } \\
\text { hemolysis }\end{array}$ \\
\hline SK & 69.23 & -- \\
ASA & -- & $61.33 \pm 0.004$ \\
POME & 3.44 & $14.67 \pm 0.001$ \\
MKME & 29.16 & $36.00 \pm 0.003$ \\
BMME & 57.81 & $10.67 \pm 0.001$ \\
\hline
\end{tabular}

In this study, the stabilization of RBC membrane by the methanolic crude extract of $P$. ocymoides, $M$. koenigii and B. montanum was found to be moderate (Table 8). Previously, it has been reported that certain bioactive secondary metabolites isolated from plant 
sources were capable of stabilizing the RBC membrane and this may be indicative of their ability to exert anti- inflammatory activity. ${ }^{34}$

\section{CONCLUSIONS}

It can be concluded that the methanol extracts of $P$. ocymoides, $M$. koenigii and $B$. montanum exhibited moderate antidiarrheal, antipyretic, analgesic and anxiolytic activities in animal models. These properties strongly support the ethnopharmacological uses of these plants in Bangladesh. However, further phytochemical and pharmacological investigations of the active compounds from these plants should be conducted for extensive traditional uses and potential therapeutic applications.

\section{REFERENCES}

1. Ghani, A. 2003. Medicinal Plants of Bangladesh: Chemical constituents and uses. 2nd edition, Asiatic society of Bangladesh, Dhaka.

2. Kuddus, M.R., Rumi, F., Haque, M.R., Hassan, M.A. and Rashid, M.A. 2013. Assessment of antioxidant, antimicrobial and cytotoxic properties of fruits of Melocanna baccifera (Roxb.)Kurz. Turkish J. Pharm. Sci. 10, 185-192.

3. Ali, M.S., Dey, A., Sayeed, M.A., Rahman, A.A., Kuddus, M.R. and Rashid, M.A. 2014. In vivosedative and cytotoxic activities of methanol extract of leaves of Crataeva nurvala Buch-Ham. Pakistan J. Biol. Sci. 17, 439-442.

4. Asif, M. 2012. Phytochemical study of polyphenols in Perilla frutescens as an antioxidant. Avicenna J. Phytomed.2, 169178

5. Asif, M. 2011. Health effects of omega-3,6,9 fatty acids: Perilla frutescens is a good example of plant oils. Orient. Pharm. Exp. Med.11, 51-59.

6. Makino, T., Furuta, Y., Wakushima, H., Fujii, H., Saito, K. and Kano,Y. 2003. Anti-allergic effect of Perilla frutescens and its active constituents. Phytother. Res. 17, 240-243.

7. Arulselvan, P., Senthilkumar, G.P., Kumar, D.S. and Subramanian, S. 2006. Anti-diabetic effect of Murraya koenigii leaves on streptozotocin-induced diabetic rats. Pharmazie 61,874-877.

8. Shah, A.S., Wakade, A.S. and Juvekar, A.R. 2008. Immunomodulatory activity of methanolic extract of Murraya koenigii Spreng leaves. Ind. J. Exp. Biol. 46, 505509.
9. Prajapati, N.D., Purohit, S.S., Sharma, A.K. and Kumar, T.A. 2003. In: Book of Medicinal Plants. 1st ed. Jodhpur, Rajasthan: Agrobios.

10. Narasimhan, N.S., Paradkar, M.V., Chitguppi, V.P. and Kelkar, S.L. 1975. Alkaloids of Murraya koenigii: structures of mahanimbine, koenimbine, (-)- mahanine, koenine, koenigine, koenidine and (+)-isomahanimbine. Indian $J$. Chem.13, 993-999.

11. Rastogi, R.P. and Mehrotra, B.N. 1980. Compendium of Indian medicinal plants. vol. 2. New Delhi, India: Central Drug Research Institute and National Institute of Science Communication and Information Resources.

12. Kureel, S.P., Kapil, R.S. and Popli, S.P. 1969. Terpenoid alkaloids from Murraya koenigii Spreng.-II. The constitution of cyclomahanimbine, bicyclomahanimbine, and mahanimbidine. Tetrahedron Lett. 10, 3857-3862.

13. Ramsewak, R.S., Nair, M.G., Strasburg, G.M., DeWitt, D.L. and Nitiss, J.L. 1999. Biologically active carbazole alkaloids from Murraya koenigii. J. Agric. Food Chem.47, 444-447.

14. Johnson, M., Wesely, E.G., Hussain, M.I.Z. and Selvan, N. 2010. In vivo and in vitro phytochemical and antibacterial efficacy of Baliospermum montanum (Willd.) Muell. Arg. Asian Pacific J. Tropical Med.3, 894-897.

15. Kinghorn, A. D. 1979. Carcinogenic irritant Euphorbiaceae in toxic plants. Ed. A. D. Kinghorn,Columbia University Press, New York, pp. 137-160.

16. Anjum, A., Sultan, Z.M., Hasan, C.M. and Rashid, M.A. 2017. Antibacterial and cytotoxic constituents from Bridelia verrucosa Haines growing in Bangladesh Dhaka Univ. J. Pharm. Sci. 16, 61-68.

17. Khair, M.A., Ibrahim ,M., Ahsan, Q., Kuddus, M.R.,Rashid, R.B. and Rashid, M.A. 2014. Preliminary phytochemical screenings and pharmacological activities of Blumea lacera(Burn.f.) DC. Dhaka Univ. J. Pharm. Sci.13, 63-69.

18. Zimmermann, M. 1983. Ethical guidelines for investigations of experimental pain in conscious animals. Pain 16, 109-110.

19. Evans, W.C. and Trease. 2002. Pharmacognosy. London: WB Saunders Ltd, pp. 32-33, 95-99, 512, 547.

20. Ali, M. 2009. Text Book of Pharmacognosy. New ed. CBS Publishers and Distributors. New Delhi, India, pp.96-97, 140 and 283.

21. Sultan, M.Z. and Rashid, M.A. 2014. Experimental Organic, Medicinal and Natural Product Chemistry, Ashrafia Boighar, Dhaka, Bangladesh.

22. Bauer, A.W., Kirby, W.M., Sherris, J.C. and Turck. M. 1966. Antibiotic susceptibility testing by a standardized single disk method. Am. J. Clin. Pathol. 45, 493-496.

23. Shoba, F.G and Thomas, M. 2001. Study of antidiarrhoeal activity of four medicinal plants in castor oil-induced diarrhea. J. Ethnopharmacol. 76, 73-76. 
24. Olajide, O.A., Echianu, C.A., Adedapo, A.D. and Makinde, J.M. 2004. Anti-inflammatory studies on Adenanthera pavonina seed extract. Inflammopharmacol.12, 196-202.

25. Gupta, A.K., Parasar, D., Sagar, A., Choudhary, V., Chopra, B.S., Garg, R., Ashish, and Khatri, N. 2015. Analgesic and anti-inflammatory properties of gelsolin in acetic acid induced writhing, tail immersion and carrageenan induced paw edema in mice. PLOS One10, e0135558. (https://doi.org/10.1371/journal.pone.0135558)

26. Naveed, M., Saeed, M. and Khan, H. 2012. Antipyretic, analgesic and anti-inflammatory activity of Viola betonicifolia whole plant. BMC Complement. Alternat. Med.12, 59. (https://doi.org/10.1186/1472-6882-12-59)

27. Kishore, R.N., Anjaneyulu, N., Ganesh, M.N. and Sravya, N. 2012. Evaluation of anxiolytic activity of ethanolic extract of Foeniculum vulgare in mice model. Int. J. Pharm. Pharm. Sci. 4, 584-586.

28. Prasad, S., Kashyap, R.S., Deopujari, J.Y., Purohit, H.J., Taori, G.M. and Daginawala, H.F. 2006. Development of an in vitro model to study clot lysis activity of thrombolytic drugs.Thrombosis J. 4, 14. (https://doi.org/10.1186/14779560-4-14).

29. Shinde, U.A., Phadke, A.S., Nair, A.M., Mungantiwar, A.A., Dikshit, V.J. and Saraf, M.N. 1999. Membrane stabilizing activity-a possible mechanism of action for the antiinflammatory activity of Cedrus deodara wood oil. Fitoterapia 70, 251-257.
30. Bahekar, S.E. and Kale, R.S. 2015. Antidiarrheal activity of ethanolic extract of Manihot esculenta Crantz leaves in Wistar rats. J. Ayurveda Integr. Med. 6, 35-40.

31. Contarino, A., Dellu, F., Koob, G.F., Smith, G.W., Lee, K., Vale, W. and Gold, L.H. 1999. Reduced anxiety-like and cognitive performance in mice lacking the corticotrophinreleasing factor receptor 1. Brain Res. 835, 1-9.

32. Unis, A.S., Cook, E.H., Vincent, J.G., et al., 1997. Platelet serotonin measures in adolescents with conduct disorder. Biol. Psych. 42, 553-559.

33. Ali, MR., Hossain, M., Runa, J.F., Hasanuzzaman, M. and Islam, M.M. 2014. Evaluation of thrombolytic potential of three medicinal plants available in Bangladesh, as a potent source of thrombolytic compounds. Avicenna J. Phytomed. 4, 430-436.

34. Oyedapo, O.O. and Famurewa, A.J. 1995. Antiprotease and membrane stabilizing activities of extracts of Fagara zanthoxyloides, Olax subscorpioides and Tetrapleura tetraptera. Int. J. Pharmacog. 33, 65-69. 